\title{
Comparative effects of wheat bran and barley husk on nutrient utilization in rats
}

\author{
2. Zinc, calcium and phosphorus*
}

\author{
BY CARMEN M. DONANGELO $†$ AND B. O. EGGUM \\ National Institute of Animal Science, Animal Physiology and Biochemistry, \\ 25 Rolighedsvej, DK-1958 Frederiksberg C, Denmark
}

(Received 3 May 1985 - Accepted 11 February 1986)

1. The present work was undertaken to study comparatively the effect on mineral availability in rats of wheat bran and barley husk when supplying the same amount of dietary fibre (DF). The experiment involved a total of nine dietary treatments including a control group and two series of four groups with increasing amounts of fibre from the two sources (total DF ranging from 42 to $117 \mathrm{~g} / \mathrm{kg}$ dry matter (DM)). Dietary nitrogen concentration was kept constant at $15 \mathrm{~g} \mathrm{~N} / \mathrm{kg}$ DM. Zinc concentration of the diets was adjusted to the level provided by the diet with the highest wheat-bran content $(21 \mathrm{mg} / \mathrm{kg} \mathrm{DM})$ using zinc sulphate. Other minerals were not adjusted.

2. Two experiments were performed. In Expt 1 the diets were given to 5-week-old rats during $9 \mathrm{~d}$ and apparent absorptions of $\mathrm{Zn}$, calcium and phosphorus and the femur concentrations of $\mathrm{Zn}, \mathrm{Ca}$ and $\mathbf{P}$ were measured. In Expt 2 the diets were given to 9-week-old rats during $12 \mathrm{~d}$. Mineral concentration in femur and total and albumin-bound plasma $\mathrm{Zn}$ and availability of plasma $\mathrm{Zn}$ for enzyme reactivation were measured.

3. In the younger animals, wheat bran depressed significantly the absorption of $\mathrm{Zn}$ when providing $40 \mathrm{~g} \mathrm{DF} / \mathrm{kg}$ $\mathrm{DM}$ and absorbtion of $\mathrm{Ca}$ when providing $80 \mathrm{~g} \mathrm{DF} / \mathrm{kg}$ DM. Barley husk depressed significantly both the absorption of $\mathrm{Zn}$ and $\mathrm{Ca}$ already at $20 \mathrm{~g} \mathrm{DF} / \mathrm{kg}$ DM. Both fibre sources had a more negative effect on $\mathrm{Zn}$ than on Ca absorption. Only barley husk had a small negative effect on absorption of P. Phytate did not appear as a major factor affecting mineral absorption in barley husk. All diets containing barley husk had a very low molar ratio, phytate: $Z n$.

4. The age of the animals influenced the utilization of dietary minerals using femur concentration as a criterion, particularly in the case of $\mathrm{Zn}$. In the younger animals the decrease in femur $\mathrm{Zn}$ with fibre correlated with apparent $\mathrm{Zn}$ absorption both with wheat bran $\left(R^{2} 0.986, P<0.01\right)$ and with barley husk $\left(R^{2} 0.996, P<0 \cdot 01\right)$. In the older animals femur $\mathrm{Zn}$ did not change significantly with fibre.

5. In the older animals, plasma $\mathrm{Zn}$, albumin-bound plasma $\mathrm{Zn}$ and availability of plasma $\mathrm{Zn}$ for enzyme reactivation were lowest with the highest addition of wheat bran.

Wheat bran has been extensively tested for its effects on mineral biological availability, and mainly phytate (Davies et al. 1977; Davies \& Olpin, 1979; Morris \& Ellis, 1980; Andersson et al. 1983; Nävert et al. 1985) but also fibre (Reinhold et al. 1975; Van Dokkum et al. 1982) have been implicated in reduced absorption of minerals, particularly zinc. Considerably less information has been gathered about the effect of fibre-rich fractions of other cereals with respect to mineral availability (Frølich, 1984). Clearly, results obtained with one cereal product do not necessarily apply to others because of differences in fibre level, fibre composition, phytate content and other less well recognized factors that may interfere with mineral utilization.

The purpose of the present study was to compare the effects of wheat bran and barley husk on mineral availability in rats as part of a larger study in which the effects of these cereal fractions on the availability of protein and energy were also investigated (Donangelo \& Eggum, 1985). Wheat bran and barley husk differ markedly in their chemical composition,

* Paper no. 1: British Journal of Nutrition (1985), 54,741-751.

$\dagger$ Present address: Instituto de Nutricao, Universidade Federal do Rio de Janeiro, Ilha do Fundao, 21910 Rio de Janeiro, Brazil.

$\ddagger$ For reprints. 
wheat bran being richer in protein, minerals and phytate while barley husk contains considerably more fibre (Donangelo \& Eggum, 1985). The chemical composition of the fibre is also different (K. E. Bach Knudsen, personal communication). Barley-husk fibre contains more lignin than does wheat bran and a higher proportion of glucose units in the nonstarch-polysaccharide fraction. Wheat-bran fibre contains proportionally more arabinose units and slightly more uronic acid in the non-starch-polysaccharide fraction.

Information about the effect on mineral availability of fibre-rich barley fractions may be relevant both for animal and human nutrition. Barley ranks fourth in the world's total cereal production (Munck, 1981) and although at present the major part of the production is grown for animal feed it still represents a staple food in the Middle East and is widely used in many Asian countries (Munck, 1981). Indirect information of the effect of barley husk on $\mathrm{Zn}$ utilization has been obtained by Pedersen \& Eggum (1983) in rats. Barley milled into flours of decreasing extraction rates were given to growing rats and only the animals that received the most refined flours were able to maintain their femur $\mathrm{Zn}$ concentration in spite of lower $\mathrm{Zn}$ intakes. The effect on other minerals was not investigated.

Because wheat bran and barley husk differ in their content of at least two components that may affect mineral utilization, namely phytate and fibre, we designed our study in order to compare the effects of both sources when supplying the same amount of fibre. Increasing levels of fibre from both sources were given to rats in diets in which $\mathrm{Zn}$ concentration was adjusted to a constant level above requirement, and their effect on the apparent absorption of $\mathrm{Zn}$, calcium and phosphorus were compared. The effect of age on the animals utilization of $\mathrm{Ca}, \mathrm{P}$ and $\mathrm{Zn}$ in these diets was also investigated.

\section{EXPERIMENTAL \\ Design}

A total of nine dietary treatments were tested, including a control group without wheat bran or barley husk added, and two series of four groups with increasing amounts of fibre from each cereal fraction. Fibre contribution from either source at each level of fibre in the test diets was identical. The $\mathrm{Zn}$ content of all diets was adjusted to the level provided by the highest wheat-bran diet using zinc sulphate.

Two experiments were performed. In Expt 1, the diets were given to rapidly growing rats (5-week-old) and apparent absorption of $\mathrm{Zn}, \mathrm{Ca}$ and $\mathrm{P}$, and contents of $\mathrm{Zn}, \mathrm{Ca}$ and $\mathrm{P}$ in the femurs were measured. In Expt 2, the same diets were given to older rats (9-week-old). The mineral content in the femurs was measured and information about distribution and availability of $\mathrm{Zn}$ in plasma was obtained in these animals by measuring total plasma $\mathrm{Zn}$, albumin-bound plasma $\mathrm{Zn}$ and availability of plasma $\mathrm{Zn}$ for restoration of the activity of a $\mathrm{Zn}$ bacterial metallo-enzyme inactivated by metal chelation.

\section{Diets}

The control diet was composed of casein supplemented with $10 \mathrm{~g}$ DL-methionine/ $\mathrm{kg}$ dry matter (DM) and wheat flour (80\% extraction rate) as protein sources, each providing half the dietary protein $(98 \mathrm{~g} / \mathrm{kg} \mathrm{DM})$; a basal $\mathrm{N}$-free mixture consisting of $(\mathrm{g} / \mathrm{kg} \mathrm{DM})$ : autoclaved potato starch 806.0 , sucrose 90.0 , cellulose $50 \cdot 0$, soya-bean oil 52.0 ; a mineral mixture (see Table 1) without $\mathrm{Zn}$ included; and a vitamin mixture (see Table 1).

In the test diets, wheat bran (bran series, diets $1,2,3,4$ ) or barley husk (husk series, diets $1,2,3,4)$ was added at increasing levels so that diets with the same number of both series contained the same level of total dietary fibre (DF). The addition of wheat bran or barley husk was done at the expense of wheat flour, keeping constant the dietary protein. The $\mathrm{Zn}$ content of all diets was adjusted to the level provided by diet 4 of the bran series, using 
Fibre and mineral utilization in rats

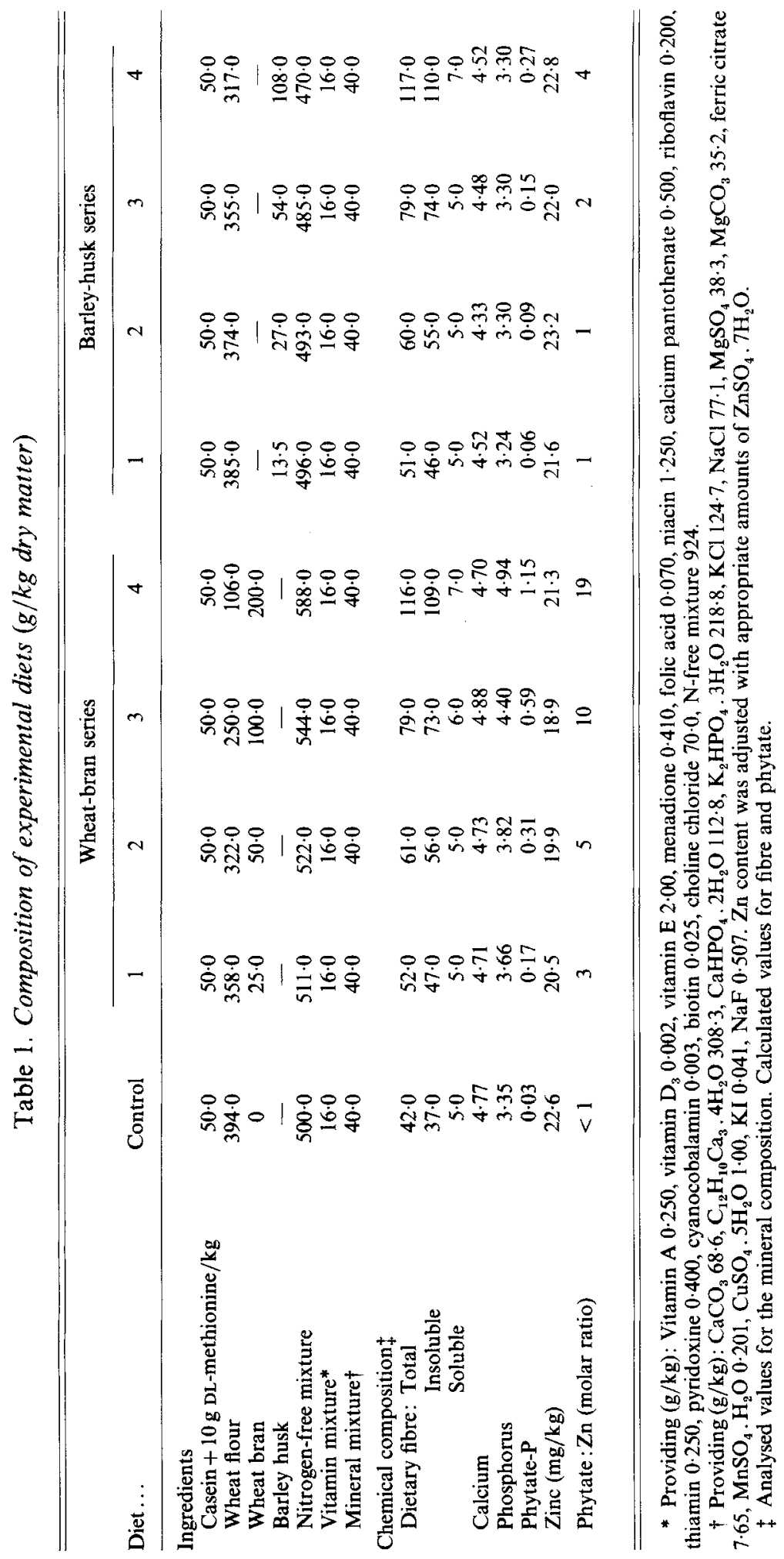


appropriate amounts of $\mathrm{ZnSO}_{4} \cdot 7 \mathrm{H}_{2} \mathrm{O}$. The formulation and chemical composition of the experimental diets are given in Table 1 (see also Table 2).

\section{Animals, feeding and tissue collection}

Expt 1. Groups of five Wistar male 5-week-old rats, weighing on average $72 \mathrm{~g}$, were assigned to each dietary treatment. Mean weights between groups at the beginning of the experiment differed by no more than $0.5 \mathrm{~g}$. The rats were housed individually in Plexiglass metabolism cages with stainless-steel-mesh bottoms in a controlled environment (temperature $25^{\circ}$, relative humidity $50 \%$, light-dark periods of $12 \mathrm{~h}$ ). Each animal received $10 \mathrm{~g}$ dietary $\mathrm{DM}$ and $150 \mathrm{mg} \mathrm{N}$ daily. Redistilled water was supplied ad lib. The diets were given for $9 \mathrm{~d}$ and body-weight and diet intake were monitored during the last $5 \mathrm{~d}$.

Faeces were collected during the last $5 \mathrm{~d}$ of the feeding period as already described (Eggum, 1973). The faeces were lyophilized and ground into a fine powder using a mortar and pestle before mineral analyses. All materials, including the cages, in direct contact with the rats, and diets and faeces, were acid-washed in $4 \mathrm{M}$-nitric acid and thoroughly rinsed with redistilled water before use.

At the end of the experiment the animals were killed and femurs were dissected and carefully cleaned of adherent tissue using stainless-steel instruments. Femurs were placed in pre-weighed, acid-washed Pyrex tubes and dried overnight at $100^{\circ}$. Dry weights were recorded. Wet ashing for mineral analysis was carried out in the same tubes as described later.

Expt 2. The same diets were given, using the same precautions and conditions of Expt 1 , to groups of five Wistar male 9-week-old rats weighing on average $160 \mathrm{~g}$. The animals had been previously fed on a commercial diet containing $100 \mathrm{mg} \mathrm{Zn} / \mathrm{kg} \mathrm{DM}$ for $10 \mathrm{~d}$. During the experiment each animal received $15 \mathrm{~g}$ dietary DM and $225 \mathrm{mg} \mathrm{N}$ daily during $12 \mathrm{~d}$. At the end of this period the animals were anaesthetized by intramuscular injection of $100 \mu 1$ Immobilon (Pharmacia) and, while unconscious, blood was drawn from the heart, using 19-gauge stainless-steel needles and disposable plastic syringes. Blood was transferred into a $\mathrm{Zn}$-free lithium heparin tube and plasma separated by centrifugation. Plasma samples were kept in $\mathrm{Zn}$-free plastic tubes at $-20^{\circ}$ until analysed. Femurs were dissected, cleaned, dried and analysed for minerals as for the smaller animals.

\section{Analytical methods}

TDF was analysed by a gravimetric method based on the digestion of the sample by a heat-resistant $\alpha$-amylase (EC 3.2.1.1) followed by pepsin and pancreatin, as described by Asp et al. (1983). Phytic acid was determined after extraction with trichloroacetic acid, precipitation as ferric salt and measurement of the iron content by colorimetry, as described by Wheeler \& Ferrel (1971).

Before mineral analysis, dietary components, diets, faeces and dried femurs were wet digested with $16 \mathrm{M}-\mathrm{HNO}_{3}$ and $12 \mathrm{M}$-perchloric acid in a low-temperature digestor (Tecator). The temperature was raised very slowly to about $180^{\circ}$ and kept constant until complete digestion. The resulting digests were diluted to appropriate volumes and analysed for $\mathrm{Zn}$ and $\mathrm{Ca}$ by atomic absorption spectrophotometry (Pye Unicam SP 9). The same digest was also used for determination of $P$ as described by Stuffins (1967).

Total and albumin-bound plasma $\mathrm{Zn}$ were analysed as described by Giroux (1975). Availability of plasma $\mathrm{Zn}$ for Escherichia coli alkaline phosphatase (EC 3.1.3.1; ECAP) reactivation was measured by a modification of a procedure previously described (Donangelo \& Chang, 1981). A solution of 0.75 units ECAP $/ \mathrm{ml}$ (Sigma) was prepared in $0.1 \mathrm{M}$-Tris hydrochloride buffer, $\mathrm{pH} 8.5$, containing $0.5 \mathrm{~mm}$-magnesium chloride. A $100 \mu$ l portion of this solution was incubated at $37^{\circ}$ for 10 min together with $20 \mu 1$ plasma and either $1.00 \mathrm{ml}$ 
Table 2. Dietary fibre, phytic acid and mineral composition of wheat flour, wheat bran and barley husk ( $\mathrm{g} / \mathrm{kg}$ dry matter)

\begin{tabular}{|c|c|c|c|}
\hline Dietary component & Wheat flour & Wheat bran & Barley husk \\
\hline \multicolumn{4}{|l|}{ Dietary fibre } \\
\hline Total & $40 \cdot 3$ & $399 \cdot 1$ & 737.8 \\
\hline Insoluble & 27.6 & $370 \cdot 1$ & $717 \cdot 4$ \\
\hline Soluble & $12 \cdot 7$ & $29 \cdot 0$ & $20 \cdot 4$ \\
\hline Calcium & $0 \cdot 20$ & 0.66 & $1 \cdot 13$ \\
\hline Phosphorus & 1.91 & $10 \cdot 31$ & $2 \cdot 77$ \\
\hline Phytate & 0.08 & 5.72 & $2 \cdot 28$ \\
\hline Zinc (mg) & $9 \cdot 5$ & $65 \cdot 3$ & 27.6 \\
\hline Phytate: $\mathbf{Z n}$ (molar ratio) & 3 & 31 & 29 \\
\hline Fibre : $\operatorname{Zn}(\mathrm{g} / \mu \mathrm{mol})$ & 0.28 & 0.40 & 1.75 \\
\hline
\end{tabular}

Tris buffer or $1.00 \mathrm{ml} 0.5 \mathrm{-mM}$ nitrilotriacetic acid (NTA) prepared in the same buffer. Enzyme activity was measured at $410 \mathrm{~nm}$ using $10 \mathrm{~mm}$-p-nitrophenyl phosphate. Partial activity of the enzyme in the presence of NTA, related to activity when no NTA was present, was used as an indicator of availability of plasma $\mathrm{Zn}$ for ECAP reactivation. NTA completely inhibited ECAP (less than 0.05 residual activity) when no plasma was included.

\section{Statistical analyses}

The results were subjected to one-way analysis of variance (ANOVA). Differences between groups were identified by Tukey's HSD-test (Gill, 1978) Regression analyses were performed on treatment means.

\section{RESULTS}

\section{Chemical composition}

Barley husk contained almost twice as much total as well as insoluble fibre as wheat bran, but had less than half the amount of phytic acid and a much lower content of total P (Table 2 ). Wheat bran contained more than twice as much $\mathrm{Zn}$ as barley husk, 65.3 compared with $27.6 \mathrm{mg} / \mathrm{kg} \mathrm{DM}$, while Ca content was higher for barley husk. In spite of the differences in phytic acid and $\mathrm{Zn}$ concentrations, the molar ratio, phytate: $\mathrm{Zn}$ was very similar in both products (about 30 ) and considerably higher than that in wheat flour (3). Total DF: $\mathrm{Zn}$, expressed as $\mathrm{g}$ total $\mathrm{DF} / \mu \mathrm{mol} \mathrm{Zn}$, was over four times higher in barley husk than in wheat bran.

Analysed $\mathrm{Zn}$ concentration in all diets was similar (Table 1). The molar ratio, phytate: $\mathrm{Zn}$ was very low (4 or lower) in the control diet and in all diets of the barley-husk series, but it increased up to 19 in diets of the wheat-bran series. The fibre content of the control diet was derived from the wheat flour that contributed about one-third of the total amount, and from the cellulose component of the $\mathrm{N}$-free mixture. In the test diets, as wheat bran or barley husk were proportionally increased, the total as well as insoluble fibre increased up to $2 \cdot 8$ times the level in the control diet.

Although the $\mathrm{Zn}$ content of all diets was similar, the source of the $\mathrm{Zn}$ differed (Table 3 ). In the control diet as well as in diets of the barley-husk series more than half the $\mathrm{Zn}$ was provided as $\mathrm{ZnSO}_{4}$. Less $\mathrm{ZnSO}_{4}$ was required to adjust the $\mathrm{Zn}$ content in the diets of the wheat-bran series and diet 4 of this series contained no added $\mathrm{ZnSO}_{4}$. In all diets practically all the $\mathrm{Ca}$ was provided by the mineral mixture. 
Table 3. Nutrient contribution* from wheat bran and barley husk in the experimental diets

\begin{tabular}{|c|c|c|c|c|c|c|c|c|c|}
\hline \multirow[b]{2}{*}{ Diet... } & \multirow[b]{2}{*}{ Control } & \multicolumn{4}{|c|}{ Wheat-bran series } & \multicolumn{4}{|c|}{ Barley-husk series } \\
\hline & & 1 & 2 & 3 & 4 & 1 & 2 & 3 & 4 \\
\hline Total dietary fibre & - & $0 \cdot 19$ & $0 \cdot 33$ & 0.51 & 0.69 & $0 \cdot 20$ & $0 \cdot 33$ & $0 \cdot 50$ & 0.68 \\
\hline Calcium & - & $<0.01$ & 0.01 & 0.01 & 0.03 & $<0.01$ & 0.01 & 0.01 & 0.03 \\
\hline Phosphorus & - & 0.07 & $0 \cdot 14$ & 0.23 & 0.42 & 0.01 & 0.02 & 0.05 & 0.09 \\
\hline Phytate-P & - & 0.84 & 0.92 & 0.97 & 0.99 & 0.49 & 0.67 & 0.81 & 0.91 \\
\hline Iron & -- & 0.03 & 0.06 & $0 \cdot 11$ & $0 \cdot 20$ & 0.02 & 0.04 & 0.07 & $0 \cdot 14$ \\
\hline Zinc & $\overline{(0.64) \dagger}$ & $\begin{array}{c}0.08 \\
(0.56)\end{array}$ & $\begin{array}{c}0 \cdot 16 \\
(0 \cdot 48)\end{array}$ & $\begin{array}{c}0.32 \\
(0.32)\end{array}$ & $\begin{array}{c}0.64 \\
(0.00)\end{array}$ & $\begin{array}{c}0.02 \\
(0.61)\end{array}$ & $\begin{array}{c}0.03 \\
(0.61)\end{array}$ & $\begin{array}{c}0.07 \\
(0.59)\end{array}$ & $\begin{array}{c}0.13 \\
(0.56)\end{array}$ \\
\hline
\end{tabular}

* As dietary ratios.

$\dagger$ Values in parentheses correspond to proportion of $\mathrm{Zn}$ contributed by added $\mathrm{ZnSO}_{4} \cdot 7 \mathrm{H}_{2} \mathrm{O}$.

\section{Weight gain of animals}

Increasing fibre from wheat bran or barley husk did not affect significantly the mean body-weight gain of the animals: 11.5 (SD 1.3) g/5 d for the 5-week-old rats and 30.5 (SD 6.6) $\mathrm{g} / 12 \mathrm{~d}$ for the 9 -week-old rats.

\section{Apparent mineral absorption}

Information about the intake, faecal excretion and apparent absorption of $\mathrm{Ca}, \mathrm{P}$, and $\mathrm{Zn}$ in the younger animals is given in Table 4. Ca intake was fairly similar for all diets. About 0.65 of ingested $\mathrm{Ca}$ was absorbed in the control diet. Apparent $\mathrm{Ca}$ absorption decreased significantly compared with the control in the diet with the highest wheat bran contribution and for all diets containing barley husk. Apparent fractional $\mathrm{Ca}$ absorption was negatively correlated with total DF in the barley-husk diets $\left(R^{2} 0.935, P<0.01\right)$. Increasing DF from about $40 \mathrm{~g} / \mathrm{kg}$ to about $120 \mathrm{~g} / \mathrm{kg}$ from barley husk produced a decrease of $10 \%$ in the apparent fractional absorption of $\mathrm{Ca}$.

$\mathbf{P}$ intake differed in the wheat-bran and barley-husk diets because of the higher $\mathbf{P}$ content of wheat bran and a larger DM contribution of wheat bran in the total diets. In the control diet 0.64 of ingested $P$ was apparently absorbed. Apparent absorption of $P$ increased with DF provided as wheat bran but the proportion absorbed compared with intake remained fairly constant and similar to that of the control diet. When DF was increased as barley husk, apparent $P$ absorption decreased.

Apparent absorption of $\mathrm{Zn}$ decreased significantly with wheat bran only for the diets providing $0 \cdot 10$ and $0 \cdot 20$ of dietary DM from this source for all diets containing barley husk. Except for the diet with the highest fibre level, diets of the barley-husk series produced lower apparent $\mathrm{Zn}$ absorption than diets of the wheat-bran series with the same fibre contribution. Increasing dietary fibre from $40 \mathrm{~g} / \mathrm{kg}$ to about $120 \mathrm{~g} / \mathrm{kg}$ from either wheat bran or barley husk produced a decrease of over one-third that of the control value in the apparent fractional absorption of $\mathrm{Zn}$ (Fig. 1).

\section{Minerals in femur}

$\mathrm{Zn}, \mathrm{Ca}$ and $\mathrm{P}$ levels in femurs measured in the 5-week-old and 9-week-old rats are shown in Table 5 . Zn concentration in the femurs of the younger rats decreased significantly with increasing total DF in the wheat-bran and barley-husk diets. The change was more pronounced when fibre was increased as wheat bran. Femur $\mathrm{Zn}$ levels correlated significantly 


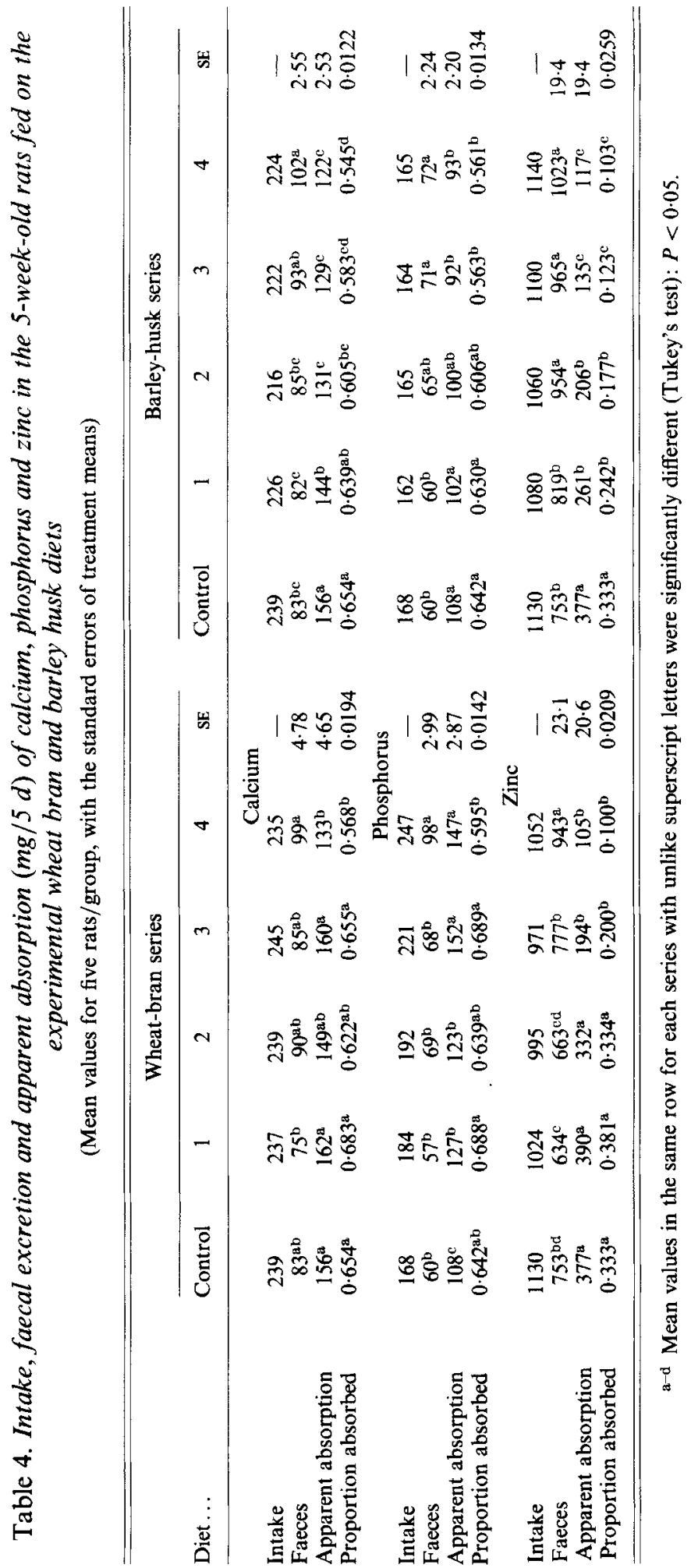




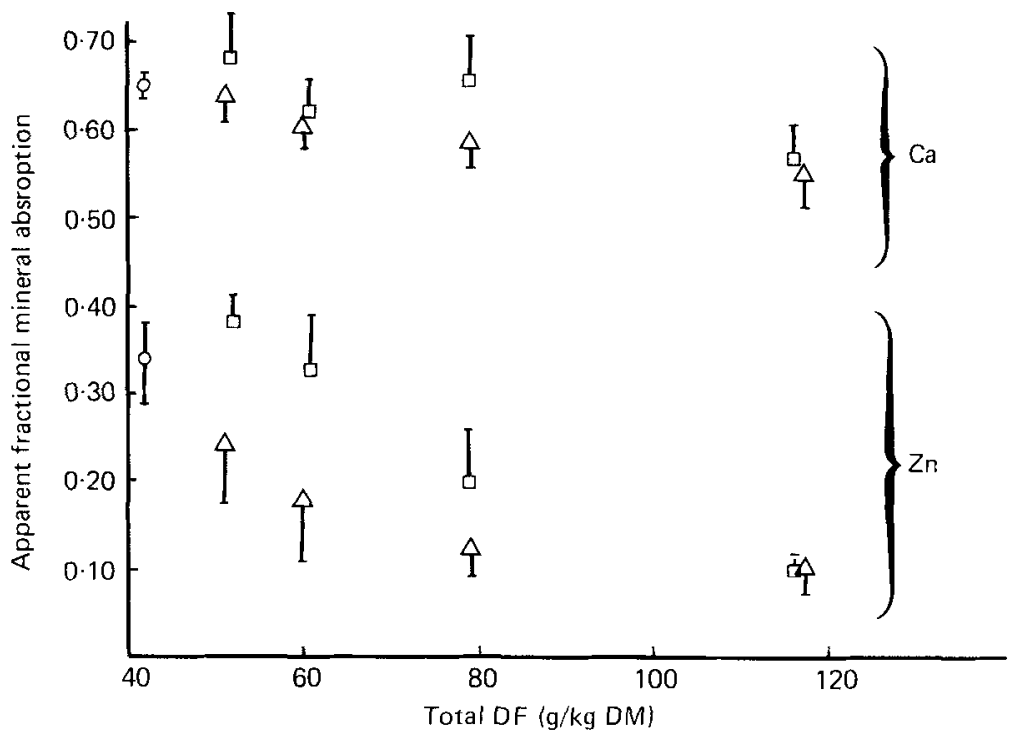

Fig. 1. Relation between total dietary fibre (DF) from wheat bran ( $\square$ ) and barley husk ( $\triangle$ ) and the apparent fractional absorption of $\mathrm{Zn}$ and $\mathrm{Ca}$. (O) Control diet.

Table 5. Mineral content (DM basis) in femurs of 5-and 9-week-old rats fed on the experimental wheat bran and barley husk diets

(Mean values for five rats/group, with the standard errors of treatment means)

\begin{tabular}{|c|c|c|c|c|c|c|c|c|c|c|c|c|}
\hline \multirow[b]{2}{*}{ Diet... } & \multicolumn{6}{|c|}{ Wheat-bran series } & \multicolumn{6}{|c|}{ Barley-husk series } \\
\hline & Control & 1 & 2 & 3 & 4 & SE & Control & 1 & 2 & 3 & 4 & $\mathrm{SE}$ \\
\hline \multicolumn{13}{|l|}{$\operatorname{Zinc}(\mu \mathrm{g} / \mathrm{g})$} \\
\hline 5-week-old & $195^{\mathrm{a}}$ & $188^{\mathrm{a}}$ & $180^{\mathrm{ab}}$ & $170^{\mathrm{bc}}$ & $159^{c}$ & $3 \cdot 24$ & $192^{a}$ & $197^{a}$ & $186^{\mathrm{ab}}$ & $175^{b}$ & $172^{\mathrm{a}}$ & $4 \cdot 37$ \\
\hline 9-week-old & $204^{a}$ & $201^{\mathrm{a}}$ & $201^{a}$ & $200^{\mathrm{a}}$ & $189^{\mathrm{a}}$ & 5.07 & $204^{\mathrm{a}}$ & $203^{a}$ & $207^{a}$ & $198^{\mathrm{a}}$ & $197^{\mathrm{a}}$ & $5 \cdot 20$ \\
\hline \multicolumn{13}{|c|}{ Calcium (mg/g) } \\
\hline 5-week-old & $174^{\mathrm{a}}$ & $173^{\mathrm{a}}$ & $171^{\mathrm{a}}$ & $172^{\mathrm{a}}$ & $173^{\mathrm{a}}$ & $2 \cdot 37$ & $174^{\mathrm{ab}}$ & $176^{\mathrm{a}}$ & $175^{\mathrm{ab}}$ & $172^{a b}$ & $168^{\mathrm{b}}$ & $1 \cdot 72$ \\
\hline 9-week-old & $190^{\mathrm{b}}$ & $197^{a b}$ & $196^{\mathrm{ab}}$ & $202^{\mathrm{b}}$ & $195^{\mathrm{ab}}$ & $2 \cdot 78$ & $190^{\mathrm{a}}$ & $190^{\mathrm{a}}$ & $191^{\mathrm{a}}$ & $190^{\mathrm{a}}$ & $186^{\mathrm{a}}$ & 2.03 \\
\hline \multicolumn{13}{|c|}{ Phosphorus (mg/g) } \\
\hline 5-week-old & $91^{\mathrm{a}}$ & $92^{\mathrm{a}}$ & $92^{\mathrm{a}}$ & $89^{a}$ & $90^{\mathrm{a}}$ & 1.07 & $91^{a}$ & $92^{\mathrm{a}}$ & $91^{\mathrm{a}}$ & $91^{\mathrm{a}}$ & $90^{\mathrm{a}}$ & 0.85 \\
\hline 9-week-old & $103^{a}$ & $102^{\mathrm{a}}$ & $103^{a}$ & $105^{a}$ & $102^{\mathrm{a}}$ & $1 \cdot 34$ & $103^{\mathrm{a}}$ & $103^{a}$ & $102^{\mathrm{a}}$ & $102^{\mathrm{a}}$ & $99^{\mathrm{a}}$ & 3.79 \\
\hline
\end{tabular}

a c Mean values in the same row for each series with unlike superscript letters were significantly different (Tukey's test): $P<0.05$.

with apparent $\mathrm{Zn}$ absorption both in the wheat-bran series $\left(R^{2} 0.986, P<0.01\right)$ and in the barley-husk series $\left(R^{2} 0.996, P<0.01\right)$. In the 9-week-old animals, although there were trends towards lower values as fibre increased, femur $\mathrm{Zn}$ did not change significantly.

$\mathrm{Ca}$ and $\mathrm{P}$ in femurs had only small changes with fibre in the younger and older animals. A significant decrease in femur $\mathrm{Ca}$ level was noted in the 5-week-old animals when barley husk was increased from 0.01 to 0.11 of dietary DM. 


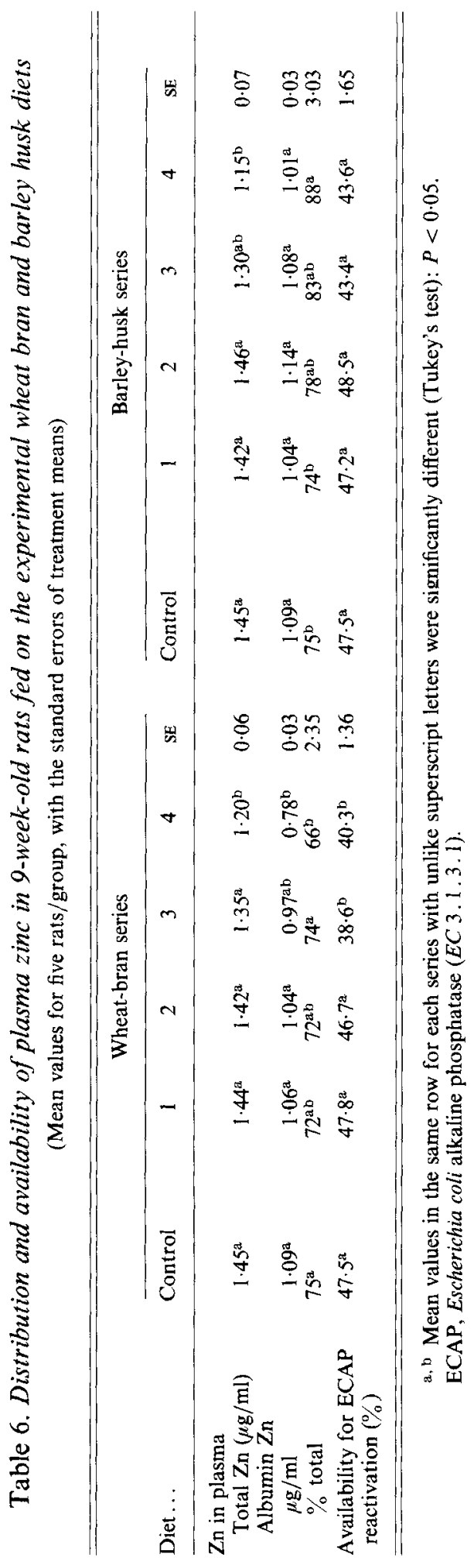




\section{Distribution and availability of plasma $\mathrm{Zn}$}

Measurements of the distribution and availability of $\mathrm{Zn}$ in plasma in the older animals are shown in Table 6. Total plasma $\mathrm{Zn}$ had a similar pattern of change in both series. It decreased significantly only with diets of higher fibre level. Plasma $\mathrm{Zn}$ bound to albumin remained fairly constant as fibre from barley husk was increased but decreased significantly for the highest wheat-bran diet. The proportion of plasma $\mathrm{Zn}$ bound to albumin was significantly smaller than the control value for the diet with the highest wheat-bran content but it increased significantly for the diet with the highest barley-husk content.

Availability of plasma Zn for restoration of ECAP activity inhibited by NTA, decreased slightly when fibre was increased in both series, but the change was significant only for the diets with the highest fibre content provided as wheat bran.

\section{DISCUSSION}

Our results indicate that wheat bran and barley husk differ in their effect on mineral availability in rats when providing the same level of dietary fibre. Both fibre sources affected $\mathrm{Zn}$ and $\mathrm{Ca}$ absorption in the younger animals but to a different extent. Wheat bran decreased $\mathrm{Zn}$ absorption when contributing over $0 \cdot 10$ of dietary DM, i.e. $40 \mathrm{~g} \mathrm{DF} / \mathrm{kg} \mathrm{DM}$ or more. Barley husk influenced $\mathrm{Zn}$ absorption when contributing 0.03 of dietary DM, i.e. less than $20 \mathrm{~g} \mathrm{DF} / \mathrm{kg}$ DM. Wheat bran decreased $\mathrm{Ca}$ absorption only when providing about $80 \mathrm{~g} \mathrm{DF} / \mathrm{kg} \mathrm{DM}$ while the effect of barley husk was evident already when providing $20 \mathrm{~g}$ $\mathrm{DF} / \mathrm{kg} \mathrm{DM}$. Both fibre sources had a more pronounced negative effect on $\mathrm{Zn}$ than on $\mathrm{Ca}$ absorption. Only barley husk had a small negative effect on $\mathrm{P}$ absorption when included at 0.05 of dietary DM or more.

Most animal and human studies have pointed out an inhibitory effect of wheat bran on Zn absorption (Davies et al. 1977; Morris \& Ellis, 1980; Sandberg et al. 1982: Nävert et al. 1985). Many of the studies attribute this effect to phytate (Davies et al. 1977; Morris \& Ellis, 1980; Andersson et al. 1983; Nävert et al. 1985).

Although from our study we cannot conclude which factor(s) in the products tested reduced $\mathrm{Zn}$ absorption, it seems that phytic acid is not the only one involved, at least in the case of barley husk. The molar ratio, phytate: $\mathrm{Zn}$ in all diets containing barley husk was much lower (Table 1) than the values that have been shown to affect $\mathrm{Zn}$ utilization. When $\mathrm{Zn}$ was given at the level of requirement, dietary phytate caused significant reductions in growth rate, hair $\mathrm{Zn}$ concentration and plasma $\mathrm{Zn}$ in rats for phytate: $\mathrm{Zn}$ values of 15 and 10 (Davies \& Olpin, 1979). When femur $\mathrm{Zn}$ was used as the criterion, lower values than those of the controls were obtained only when phytate: $\mathrm{Zn}$ was 25 at $0.75 \%$ of dietary $\mathrm{Ca}$ or 20 at $1.75 \%$ of dietary $\mathrm{Ca}$.

In a study by Forbes et al. (1984), a reduction in rat tibia $\mathrm{Zn}$ was obtained at a phytate: $\mathrm{Zn}$ value of 20 when molar $\mathrm{Ca}: \mathrm{Zn}$ was 680 and more phytate was needed (phytate: $\mathrm{Zn} 30$ ) to produce the same effect at a $\mathrm{Ca}: \mathrm{Zn}$ value of 400 . In all our experimental diets the molar $\mathrm{Ca}: \mathrm{Zn}$ value was about 400 or lower.

Supporting the hypothesis that phytate is not entirely involved in reduced $\mathrm{Zn}$ availability in barley, Pedersen \& Eggum (1983) observed that femur $\mathrm{Zn}$ in rats fed on whole-barley flours with similar phytate contents but different $\mathrm{Zn}$ contents, were very similar in spite of quite different phytate: $\mathrm{Zn}$ values (39 and 24 ).

It is likely that the fibre in barley husk is responsible for its effect on $\mathrm{Zn}$ absorption and its high lignin content could contribute to this effect since lignin has been shown to bind strongly divalent cations including $\mathrm{Zn}, \mathrm{Ca}$ and $\mathrm{Fe}$ at intestinal $\mathrm{pH}$ in vitro (Camire \& Clydesdale, 1981). However, the effect of other components besides fibre cannot be 
excluded. Barley can contain considerable levels of tannins (Eggum \& Christensen, 1975) and this component could also be involved, although polyphenols do not seem to affect $\mathrm{Zn}$ availability, at least in field beans (Vicia faba) (Lantzsch \& Scheuermann, 1982).

The addition of wheat bran to bread has been shown to cause negative Ca balance in human subjects (Cummings et al.1979) and phytate has also been implicated as a major factor in reduced $\mathrm{Ca}$ absorption (Andersson et al. 1983). However, as suggested by the present study, the negative effect of wheat bran on $\mathrm{Ca}$ absorption seems to occur only at moderately high levels in the diet. In rats, no effect was evident with $150 \mathrm{~g}$ wheat $\mathrm{bran} / \mathrm{kg}$ (Kunkel et al. 1984) and in human subjects no effect was observed using $16 \mathrm{~g}$ wheat bran/d (Sandberg et al. 1982). As for $\mathrm{Zn}$, the adverse effect of barley husk on Ca absorption could be due to the lignin content of the fibre and to other components together with phytate.

The high absolute absorption of $P$ with increasing levels of wheat bran indicates that the additional dietary $P$ contributed by wheat bran is absorbed to some extent. A substantial proportion of phytate-P from wheat bran seems to be hydrolysed in the rat intestinal tract (Ballam et al. 1984) and phytase activity in the small intestine of rats has been found to be higher than that in other mammalian species (Cooper \& Gowing, 1983). This ability to hydrolyse phytate may be an important factor influencing mineral availability in rats. In contrast to wheat bran, our study suggests that $\mathbf{P}$ from barley husk was not available for absorption.

One aspect of our study was to investigate the influence of age of the animals on the utilization of minerals of the diets using femur content as a criterion. Mineral changes in femurs with increasing age and DF were most evident in the case of $\mathrm{Zn}$. In the younger animals the decrease in femur $\mathrm{Zn}$ paralleled $\mathrm{Zn}$ absorption. However, in older animals, femur $\mathrm{Zn}$ did not show significant changes with changes in DF. Femur $\mathrm{Zn}$ is regarded as a sensitive indicator of $\mathrm{Zn}$ status (O'Dell, 1984) but we conclude that the age of the animal is an important factor influencing femur $\mathrm{Zn}$ response to diet when a relatively short period is used.

Increasing DF from wheat bran and barley husk did influence measurements of plasma $\mathrm{Zn}$ in the older animals. Plasma $\mathrm{Zn}$, albumin-bound plasma $\mathrm{Zn}$ and availability of plasma $\mathrm{Zn}$ for ECAP reactivation decreased mainly with the highest level of wheat bran. Since albumin together with amino acid-bound $\mathrm{Zn}$ constitute the loosely-bound pool of plasma $\mathrm{Zn}$ directly taken up by tissues (Prasad \& Oberleas, 1970; Giroux \& Henkin, 1972; Giroux et al. 1976) lower albumin-bound $\mathrm{Zn}$ would indicate that less circulating $\mathrm{Zn}$ is available to tissues. In agreement with this, availability of plasma for restoration of activity of ECAP in a test-tube was lowest for lower albumin-bound $\mathrm{Zn}$ concentrations.

This study was designed to compare the effect of wheat bran and barley husk on mineral utilization when providing the same level of fibre and with dietary minerals consisting of a mixture of endogenous orgin and inorganic salts added. Although the experimental design does not allow differentiation of the specific fate of both sources of minerals it seems likely that the results obtained, at least in the case of $\mathrm{Zn}$, were influenced to some extent by the chemical form in which $\mathrm{Zn}$ was provided in the diets. Forbes \& Parker (1977) and Hardie-Muncy \& Rasmussen (1979) have clearly demonstrated that inorganic $\mathrm{Zn}$ added to soya-bean products is of higher biological availability compared with the endogenous $\mathrm{Zn}$ of the product. In the present study, the diet with the highest wheat bran content and with no added inorganic $\mathrm{Zn}$ produced a very low apparent absorption of $\mathrm{Zn}$, and the lowest values of femur $\mathrm{Zn}$ and $\mathrm{Zn}$ measurements in plasma.

The authors are most indebted to the Danish Agricultural and Veterinary Research Council for financial support.

The authors are grateful to Dr Birthe Pedersen for helpful discussions and critical reading 
of the manuscript. The technical assistance of Ms D. Hansen, Ms V. Nielsen, Mr H. Laursen and Ms A. Tommerup is also gratefully acknowledged.

\section{REFERENCES}

Andersson, H., Nävert, B., Bingham, S. A., Englyst, H. N. \& Cummings, J. H. (1983). British Journal of Nutrition 50, 503-510.

Asp, N.-G., Johansson, C.-G., Hallmer, H. S. \& Siljeström, M. (1983). Journal of Agricultural and Food Chemistry 31, 476-482.

Ballam, G. C., Talmadge, S. N. \& Kirby, L. K. (1984). Nutrition Reports International 30, 1089-1100.

Camire, A. L. \& Clydesdale, F. M. (1981). Journal of Food Science 46, 548-551.

Cooper, J. R. \& Gowing, H. S. (1983). British Journal of Nutrition 50, 673-678.

Cummings, J. H., Hill, M. J., Jivraj, T., Houston, H., Branch, W. J. \& Jenkins, D. J. A. (1979). American Journal of Clinical Nutrition 32, 2086-2093.

Davies, N. T., Hristic, V. \& Flett, A. A. (1977). Nutrition Reports International 15, 207-214.

Davies, N. T. \& Olpin, S. E. (1979). British Journal of Nutrition 41, 591-603.

Donangelo, C. M. \& Chang, G. W. (1981). Clinica Chimica Acta 1130, 201-206.

Donangelo, C M. \& Eggum, B. O. (1985). British Journal of Nutrition 54, 741-751.

Eggum, B. O. (1973). National Institute of Animal Science, Copenhagen Report no. 406, p. 173.

Eggum, B. O. \& Christensen, K. D. (1975) In Breeding for Seed Protein Improvement Using Nuclear Techniques, pp. 135-143. Vienna: International Atomic Energy Agency.

Forbes, R. M. \& Parker, H. M. (1977). Nutrition Reports International 15, 681-688.

Forbes, R. M., Parker, H. M. \& Erdman, J. W. Jr (1984). Journal of Nutrition 114, 1421-1425

Frølich, W. (1984). Bioavailability of minerals from unrefined cereal products. In vitro and in vivo studies. PhD Thesis, University of Lund, Sweden.

Gill, J. L. (1978). Design and Analysis of Experiments in the Animal and Medical Sciences, vol. 1. Iowa: Iowa State University Press.

Giroux, E. L. (1975). Biochemical Medicine 12, 258-266.

Giroux, E. L., Durieux, M. \& Schechter, P. J. (1976). Bioinorganic Chemistry 5, 211-218.

Giroux, E. L. \& Henkin, R. I. (1972). Biochimica Biophysica Acta 273, 64-72.

Hardie-Muncy, D. A. \& Rasmussen, A. J. (1979). Journal of Nutrition 109, 321-329.

Kunkel, M. E., Roughead, Z. K., Gagne, C. M. \& Acton, J. C. (1984). Nutrition Reports International 29, $735-743$.

Lantzsch, H. J. \& Scheuermann, S. E. (1982). In Trace Element Metabolism in Man and Animals, pp. 114-116

[J. M. Gawthorne, J. Howell and C. L. White, editors]. Berlin: Springer-Verlag.

Morris, E. R. \& Ellis, R. (1980). Journal of Nutrition 100, 2000-2010.

Munck, L. (1981). In Cereals: A Renewable Resource. Theory and Practice, pp. 427-459 [Y. Pomeranz and L. Munck, editors]. Minnesota: American Association of Cereal Chemists.

Nävert, B., Sandström, B. \& Cederblad, A. (1985). British Journal of Nutrition 53, 47-53.

O'Dell, B. L. (1984). Nutrition Reviews 42, 301-308.

Pedersen, B. \& Eggum, B. O. (1983). Qualitas Plantarum Plant Foods for Human Nutrition 33, 99-112.

Prasad, A. S. \& Oberleas, D. (1970). Journal of Laboratory Clinical Medicine 76, 416-425.

Reinhold, J. G., Imail-Beigi, F. \& Faradji, B. (1975). Nutrition Reports International 12, 75-85.

Sandberg, A. S., Hasselblad, C., Hasselblad, K. \& Hulten, L. (1982). British Journal of Nutrition 48, $185-191$.

Stuffins, C. B. (1967). Analyst 92, 107-113.

Van Dokkum, W., Wesstra, A. \& Schippers, F. A. (1982). British Journal of Nutrition 47, 451-460.

Wheeler, E. L. \& Ferrel, R. E. (1971). Cereal Chemistry 48, 312-320. 